\title{
The Role of Organizational Culture as Moderating Variable in the Influence of Person-Organization Fit and Job Characteristics on Performance
}

\author{
Priyono, B.S. ${ }^{1)}$ \\ Economic \& Business Faculty \\ Stikubank University, Semarang, Indonesia \\ bambangsp@edu.unisbank.ac.id \\ Indrianingrum, $\mathrm{K}^{2)}$ \\ Economic \& Business Faculty \\ Stikubank University, Semarang, Indonesia
}

\author{
Murdiyanto, $\mathrm{A}^{3)}$ \\ Economic \& Business Faculty \\ Stikubank University, Semarang, Indonesia \\ Afriana, E.M ${ }^{4}$ \\ Magister Management Program \\ Stikubank University, Semarang, Indonesia
}

\begin{abstract}
This study is aimed to analyze the role of organizational culture as moderating variable in the influence of person-organization fit and job characteristics on employee performance. A survey was conducted on civil servants working for a government institution. The population in this study is $\mathbf{1 3 8}$ employees. The whole population becomes the sample of this study by using census method. This study tests the influence of person-organization fit and job characteristics on employee performance. It also test the role of organizational culture as moderating variable. There are four conclusions of this study such as 1) person-organization fit significantly positively influences employee performance, 2) job characteristics significantly positively influences employee performance, 3) organizational culture has been proven as moderating variable in the influence of person-organization fit on employee performance, and 4) organizational culture has been proven as moderating variable in the influence of job characteristics on performance This electronic document is a "live" template and already defines
\end{abstract}

Keywords: person-organization fit, job characteristics, job performance, organizational culture

\section{INTRODUCTION}

Basically, employee performance is the result of activity obtained by someone or a group in reaching the goals with particular standard. The standard is decided by organization, group, and individual within a certain term. The previous study by Hessel (2007) stated that the factors influencing employee performance are motivation, organizational culture, compensation, leadership, job satisfaction, discipline, work environment, and organizational commitment. This study is supported by Hackman \& Lawler (2001) and Kumar (2011) mentioning that employee performance is determined by job characteristics. The study conducted by Kahya (2007) shows relation between age, gender, over time work, job characteristics, work condition; and employee performance. Employee is an important factor for government institution in providing services. Therefore, evaluation needs to be done regularly. Based on secondary data, it is found that the employee performance of the government institution observed in this study is not maximal since there is gap between target and the actual result. The gap leads this study to use employee performance as dependent variable influenced by personorganization fit (P-O fit), job characteristics, and organizational culture as moderating variable.

\section{LITERATURE REVIEW}

\section{A. Person-Organization Fit}

Person-Organization fit (P-O fit) is simply defined as fit between organizational values and individual ones (Kristof, A.L, 1996; Kristof, et al., 2005; Vancouver \& Schmitt,1991). Generally, Kristof, A.L. (1996) explained that P-O fit occurs when an employee personally has high degree of fit with organizational values and characteristics. According to Kristof, et al., (2005), there are four dimensions of P-O fit such as (1) value congruence (fit between individual intrinsic value and organizational value), (2) goal Congruence (fit between individual and organizational goal), (3) employee need fulfillment (fit between employee need and environment; system; and organizational structure condition), and (4) culture- personality congruence (fit between personality and organizational culture).

\section{B. Job Characteristics}

Hackman \& Oldham (1974), Oldham \& Hackman (2010) defined job characteristics as five dimensions consisting of (1) skill variety (skills needed to complete task), (2) task identity (employee activities based on comprehension on task procedure and work involvement), (3) task significance (the importance of task related to dependence of other division, (4) autonomy (authority in making decision for job completion), and (5) feed back (response in form of information about our job result)

\section{Organizational Culture}

According to Robbins \& Judge (2017), organizational culture is a value system followed by all employees of an organization making different characteristics from others. 
There are seven dimensions of organizational culture such as (1) innovation and risk taking (organizational support for making innovation and taking risk), (2) attention on detail (organizational support for working on detail accurately), (3) result orientation (manager's focus on achievement by considering input, process, and output), (4) human orientation (each employee is demanded to contribute on achievement), (5) group orientation (organizational support on group performance) (6) aggressiveness (controlled aggressiveness and competition among employees), and 7) stability (organizational support on improvement of employees).

\section{Employee Performance}

The definition of employee performance in this study was developed from the concepts and theories of Sonnentag, S., \& Frese, M. (2005). Employee performance is a part of organizational performance measured based on its quantity and quality according to responsibility given individually. There are five dimensions of employee performance such as (1) work quality, (2) work quantity, (3) cooperation, (4) responsibility, and (5) initiative. .

\section{HYPOTHESIS DEVELOPMENT}

\section{A. Influence of Person-Organization Fit on Performance}

The previuos studies conducted by Berahmawati et al., (2019) and Maria \& Yuniawan (2016) have proven that P-O Fit positively significantly effect on employee performance. The results of these studies indicate that companies need to pay attention to employee- organization fit as a unity not only between an employee and his job. This fit results in more effective performance. The study conducted by Farooquia, S and Nagendrab, A (2014) explained that fit degree of organizational value and individual value is very important for employee performance. Individual performance determines organizational performance. Logically, fit between employee and his job is able to minimize the effort to adapt with the task given. Based on the previous study, Hypothesis 1 is arranged: Person-Organization Fit positively influences performance.

\section{B. Influence of Job Characteristics on Performance Units}

Oldham \& Hackman (2010) stated that job characteristics is able to influence job satisfaction. Employee's authority in working according to skill variety stimulates creativity, initiative, and innovation supporting internal motivation. Internal motivation influences job satisfaction and performance. The previous study by Matilu \& K'Obonyo (2018) concluded that job characteristic directly significantly influences employee performance. Oldham \& Hackman (2010) mentioned that the output of the application of Job characteristics' dimensions is high quality work performance. Job characteristics applied by an organization makes an employee feel meaningful, full of responsibility, and able to predict the result of his work. Gilbert, et al.,(1986) stated that individual and group job characteristics are related to job satisfaction, performance, and high attendance. As the conclusion, Job characteristics needs to be redesigned to improve motivation of employee in order to build better performance. Based on the previous study, Hypothesis 2 is arranged: Job characteristics positively influences performance.

\section{Influence of Organizational culture on Person- Organization Fit and Performance}

The previous study conducted by Kumar, S.S (2011), has proven that Organizational Culture moderates the effect of $\mathrm{P}$ $\mathrm{O}$ fit on Work Attitudes. This study will develop research from Kumar, S.S (2011) using employee performance variables as the dependent variable. As moderating variable, organizational culture means that it influences performance as dependent variable and $\mathrm{P}-\mathrm{O}$ fit as independent variable. According to Kristof (1996) and Vancouver et al.,(1994), Person-Organization fit is fit between organizational and individual values. Shili Sun (2008), entitled "Organizational Culture and its Themes" explained that culture in an organization holds an important role in daily activities of organization. Organizational culture is manifested in typical organizational characteristics. In other word, organizational culture must be considered as the values followed by the organization. Organizational culture is defined as deeply planted values and trust owned by employees of organization. Based on the previous study that organizational culture influences P-O fit and performance, Hypothesis 3 is arranged: Organizational Culture becomes moderating variable in the influence of $\mathrm{P}-\mathrm{O}$ fit on Performance.

\section{Influence of Organizational Culture on Job Characteristics and Performance}

Robbins \& Judge (2008) stated that organizational culture is value system followed by members of organization making difference from others. According to Shakil, A.M., (2012), organizational culture significantly positively influences performance. Suryanto (2003) stated that job characteristics and organizational culture significantly positively influence performance. It is concluded that organizational culture strengthens the influence of job characteristics on performance. Based on previous studies, Hypothesis 4 is arranged: Organizational Culture becomes moderating variable in the influence of Job Characteristics on Performance.

\section{RESEARCH METHOD}

The population in this study is 138 Civil Servants working for Trade and Industry Department in Rembang regency, Central Java, Indonesia. The sample is taken by doing census model. It is conducted by distributing questionnaire to whole population.

The variable data used in this study is collected through questionnaire. The questionnaire distributed to respondents is measured using Likert scale consisting of seven measurement range from strongly disagree to strongly agree.

Validity test in this study uses factor analysis. It is shown that KMO value of each variable is over 0.5 . It means that the sample adequacy is fulfilled. Besides, the loading factor value of all indicators of each variable is over 0.4. It means that all instruments are valid. 
Reliability test in this study using reliability analysis shows that all variable consisting of Person- Organization Fit (PO Fit), Job Characteristics, Organizational Culture, and Employee Performance are valid.

Based on the hypotheses that have been compiled, the research model in this study can be seen in Figure 1

Figure 1. Research Model

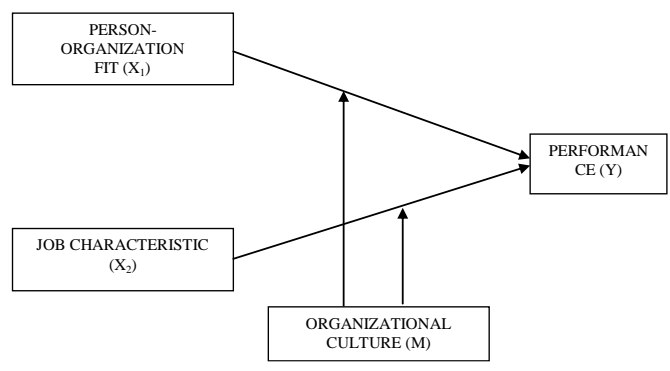

1. $\mathrm{Y}=\mathrm{a}_{1}+\beta_{1} \mathrm{X}_{1}+\beta_{2} \mathrm{X}_{2}+\mathrm{e}_{1}$

2. $Y=a_{2}+\beta_{3} X_{1}+\beta_{4} X_{1} M+e_{2}$

3. $Y=a_{3}+\beta_{5} X_{2}+\beta_{6} X_{2} M+e_{3}$

Note:

$\mathrm{Y} \quad=$ performance (dependent variable)

$\mathrm{X}_{1} \quad=$ Person-organization fit

$\mathrm{X}_{2} \quad=$ Job characteristics

$\mathrm{M}=$ Organizational culture

$\mathrm{a}_{1}-\mathrm{a}_{3}=$ constant

$\beta_{1}-\beta_{6}=$ Regression Coefficient

$\mathrm{e}_{1}-\mathrm{e}_{3}=$ error

\section{RESULTS AND ANALYSIS}

The questionnaire is distributed to 140 respondents and 136 of them are returned and proceeded. From the returned, $83.1 \%$ is male and $16.9 \%$ is female. Based on age, most of the respondents are over 43 years old $(66.9 \%)$.

Based on education background, most of them are senior high school graduates $(76.5 \%)$, and the rest $(23,5 \%)$ are from Diploma, Bachelor degree, and Magister. Based on job tenure, most of them have been working for over 15 years.

The validity test results show that all indicators in the variables are valid with $\mathrm{KMO}$ values greater than 0.5 and loading factors values greater than 0.4 . The reliability test also show that all variables in this study have Cronbach's Alpha values greater than 0.7 , which means that all variables are reliable.

The result of regression analysis is served in table 1 .

TABLE 1. REGRESSION ANALYSIS

\begin{tabular}{|c|c|c|c|c|c|c|}
\hline \multirow{2}{*}{ EQUATION } & \multirow{2}{*}{$\begin{array}{c}\text { Adjusted R } \\
\text { Square }\end{array}$} & \multicolumn{2}{|c|}{ F Test } & \multicolumn{2}{|c|}{ T test } & \multirow{2}{*}{ Remark } \\
\hline & & $\mathbf{F}$ & Sig. & $\beta$ & Sig. & \\
\hline I & \multirow{3}{*}{0.897} & \multirow{3}{*}{588.556} & \multirow{3}{*}{0.000} & & & \\
\hline $\mathrm{X} 1$ on $\mathrm{Y}$ & & & & 0.292 & 0.000 & $\begin{array}{c}\text { H } 1 \\
\text { accepted }\end{array}$ \\
\hline $\mathrm{X} 2$ on $\mathrm{Y}$ & & & & 0.752 & 0.000 & $\begin{array}{c}\mathrm{H} 2 \\
\text { accepted }\end{array}$ \\
\hline II & \multirow[b]{2}{*}{0.888} & \multirow[b]{2}{*}{535.744} & \multirow[b]{2}{*}{0.000} & & & \\
\hline$(\mathrm{X} 1 * \mathrm{M})$ on $\mathrm{Y}$ & & & & 2.427 & 0.000 & $\begin{array}{c}\text { H } 3 \\
\text { accepted }\end{array}$ \\
\hline III & \multirow[b]{2}{*}{0.901} & \multirow[b]{2}{*}{618.532} & \multirow[b]{2}{*}{0.000} & & & \\
\hline$(\mathrm{X} 2 * \mathrm{M})$ on $\mathrm{Y}$ & & & & 0.993 & 0.000 & $\begin{array}{c}\mathrm{H} 4 \\
\text { accepted }\end{array}$ \\
\hline
\end{tabular}

\section{A. Model Test}

Model test is conducted to make sure whether regression of each equation is fit or not by testing Adjusted R Square $\left(R^{2}\right)$ and $\mathrm{F}$ test (Anova).

a) Test on Adjusted $R$ Square $\left(R^{2}\right)$ : Test on Adjusted $\mathrm{R}$ Square $\left(\mathrm{R}^{2}\right)$ is done to measure the level of ability of independent variables in explaining dependent variable. Based on table 1 , it is concluded that Adjusted $\mathrm{R}^{2}$ value on equation 1 is 0.897 . It means that P-O Fit and Job Characteristics are able to explain $89.7 \%$ on Performance. While the rest $10.3 \%$ is explained by other variables outside the model.

b) F Test (Anova): $\mathrm{F}$ test is used to check simultaneous influence of independent variables on dependent variable. If significance value is below 0.05 , the model is fit. Based on table 1 , it is concluded that $\mathrm{F}$ value on equation 1 is 588.556 with significance value 0.000 (below 5\%). It means that P-O Fit and Job Characteristics simultaneously significantly positively influence performance.

\section{B. Hypothesis Test ( $t$ Test)}

a) Test on Hypothesis1: Hypothesis 1 says that P-O Fit positively influences performance. Based on table 1 , it is known that hypothesis 1 is accepted since P-O Fit significantly positively influences performance with Beta coefficient 0.292 and significance value below 5\%. It means that hypothesis 1 is accepted.

b) Test on Hypothesis 2: Hypothesis 2 says that job characteristics positively influences performance. Based on table 1 it is shown that job characteristics significanly positively influences performance with beta coefficient 0.752 and significance value below 5\%. It means that hypothesis 2 is proven.

c) Test on Hypothesis 3: Hypothesis 3 says that Organizational Culture becomes moderating variable in the influence of P-O fit on performance. Based on table 1, equation 2 is used to test moderation effect through interaction between $\mathrm{P}-\mathrm{O}$ fit and Organizational Culture $(\mathrm{X} 1 * \mathrm{M})$. The interaction results in beta coefficient positive 2.427 and significance value below 5\%. It means that Organizational Culture strengthens the influence of $\mathrm{P}-\mathrm{O}$ fit on employee performance. It is concluded that hypothesis 3 is proven.

d) Test on Hypothesis 4: Hypothesis 4 says that Organizational Culture becomes moderating variable in the influence of Job Characteristics on performance. Based on table 1 , equation 3 is used to test moderation effect through interaction between Job Characteristics and Organizational Culture $(\mathrm{X} 2 * \mathrm{M})$. The interaction results in beta coefficient positive 0.993 and significance value below $5 \%$. It means that Organizational Culture strengthens the influence of Job Characteristics on employee performance. It is concluded that hypothesis 4 is accepted. 


\section{DISCUSSION}

The result of test on hypothesis 1 has proven that person organizational fit significantly positively influences employee performance. This result supports the previous studies by Berahmawati et al., (2019) and Maria \& Yuniawan (2016) mentioning that person organizational fit significantly positively employee performance. Person organizational fit is defined as fit between organizational values and individual values (Kristof,1996; Vancouver et al.,1994). It means that higher level of organizational value -individual value fit drives better employee performance.

The result of test on hypothesis 2 shows that job characteristics significantly positively influences employee performance. This study supports the previous study by Mirwan Prastowo (2011) saying that job characteristics significantly positively influences employee performance. Hackman dan Oldham (1995) stated that Job characteristics consists of five dimensions such as skill variety, task identity, task significance, autonomy, and feed back. Higher level of fit between job characteristics and employee's ability stimulates better employee performance. Each type of job has its own typical characteristics. Each employee has different character and skill too. An employee is motivated by match between his skill and job characteristics of his work. This match is able to motivate an employee and increase performance. This result supports the previous study by Mirwan Prastowo (2011) mentioning that job characteristics significantly positively influences employee performance.

The result of test on hypothesis 3 has proven that organizational culture is moderating variable in the influence of P-O fit on employee performance. This finding supports the previous study by Abbas, M.M (2014) that organization culture can be moderating variable, and by Kumar, S.S (2011) Organization Culture is moderator between PersonOrganization (P-O) Fit and Work Attitudesby, adn by Faizal, et. al (2016) study that organizational culture positively influences performance.

The result of test on hypothesis 4 shows that organizational culture is moderating variable in the influence of Job Characteristics on performance. This result supports the previous study by Caroline M.M \& Peter K'Obonyo (2018), Ahmad (2012) saying that organizational culture strengthens the influence of job characteristics on performance.

\section{Conclusion}

Based on data analysis on hypothesis 1 and 2 , it is concluded that P-O fit and job characteristics significantly positively influence employee performance in government institution. Based on data analysis on hypothesis 3 and 4, it is concluded that Organizational Culture is strengthening moderating variable in the influence of $\mathrm{P}-\mathrm{O}$ fit on performance and in the influence of Job Characteristics on employee performance.

$\mathrm{P}-\mathrm{O}$ fit is fit between organizational values and individual values (Kristof,1996; Vancouver et al.,1994). The higher level of fit between organizational values and individual values stimulates better employee performance.
This finding supports the previous study conducted by Maria \& Yuniawan (2016) that there is significant positive relation between P-0 fit and employee performance.

This study has also shown that job characteristics significantly positively influences employee performance. Hackman \& Oldham (2010) explained that job characteristics consists of five dimensions such as autonomy, job variety, job identity, job significance, and feed back.

Job Characteristics is the typical task and responsibility as the core of each position regularly done by employee. Employee's fondness on job characteristics is able to raise his confidence in working and improve performance.

Organizational culture is able to be moderating variable in the influence of $\mathrm{P}-\mathrm{O}$ fit and job characteristics on employee performance. Therefore, it is suggested for the future study to use organizational culture as moderating variable in the influence of other variables beside $\mathrm{P}-\mathrm{O}$ fit and job characteristics on performance like empowerment, social capital, servant leadership, job involvement, and employee engagement. Employee performance is not the only possible dependent variable. It can also be organizational citizenship behavior (OCB), Job satisfaction, motivation, labor turn over intention, and career plateau. This study supported previuos study conducted by Mirwan Prastowo (2011) that there is significant positive relation between job characteristics and employee performance.

\section{ACKNOWLEDGMENT}

We would like to take this opportunity to thank Stikubank University, Semarang, Indonesia for funding this research

\section{REFERENCES}

[1] Berahmawati, E.F., Sukaria Sinulingga, Rulianda Purnomo Wibowo. (2019). The Effect of Person Job Fit and Person Organization Fit on Employee Performance. International Journal of Research \& Review 213.Vol.6; Issue: 10; October.

[2] Boulter, Dalziel dan Hill, (1996), Management of Organization Behavior, Utiliting Human, Prentice Hall, Inc.

[3] Farooquia, S and Nagendrab, A (2014). The Impact of Person organization Fit on Job Satisfaction and Performance of the Employees. Procedia Economics and Finance 11 ( 2014 ) 122 - 129.

[4] Gilbert Y.Y Wong, Philip H. Birnbaum , and Jiing-LihFarh., (1986). The Job Characteristics Model in Hong Kong, Journal of Applied Psychology 1986, Vol. 71, No.4,598-605.

[5] Hackman, J. R. \& Oldham, G. R. (1974). The job diagnostic survey: An instrument for the diagnosis of jobs and the evaluation of job redesign projects. Department of Administrative Sciences: Yale University.

[6] Kahya, Emin (2007). The effects of job characteristics and working conditions on job performance June 2007. International Journal of Industrial Ergonomics 37(6):515-523.

[7] Krietner, R. dan Kinicki (2014), Organizational Behavior. 5th Edition Mc graw-Hill : Boston.

[8] Kumar, S.S (2011), The Influence of Organizational Culture as Moderator between Person-Organization (P-O) Fit and Work Attitudes. International Journal of Management Studies (IJMS) Vol. 18, No.1 June.

[9] Kristof, A.L, 1996, Person-Organization Fit: an Integrative Review of its Conceptualizations, Measurement, and Implications. Personnel Psychology.

[10] Kristof, Brown, A.L., Zimmerman, R.D., dan Johnson E.C. 2005 Consequences of Individuals' Fit at Work: a Meta-Analysis of Person- 
Job, Person-Organization, Person-Group, and Person-Supervisorfit'. Personnel Psychology.

[11] Matilu, C.M \& K'Obonyo, P (2018) : The Relationship Between Job Characteristics and Employee Performance: A Review. International Journal of Business \& Law Research 6(3):44-59, July-Sept.

[12] Maria and Yuniawan (2016). The influence of Person Organizational Fit on Employee Performance:Organizational Commitment and Organizational Citizenship Behaviour as Intervening Variable. Economica and Business Faculty. Diponegoro University Semarang..

[13] Oldham, G.R \& Hackman, J. R., (2010). Not what it was and not what it will be: The future of job design research. First published: 22 January 2010 Journal of Organizational Behaviour, 31, 463-479.
[14] Robbins, S.P. \& Judge, T.A., (2017). Organizational Behaviour. Pearson.

[15] Shakil, A.M., (2012). Impact of organizational culture on performance. Business Intelligence Journal - January, 2012 Vol.5 No.1

[16] Shili Sun, (2008). Organizational Culture and Its Themes,. International Journal of Business and Management,. Vol.3, No. 12, December.

[17] Sonnentag, S., \& Frese, M. (2005) Performance Concepts and Performance Theory. Psychological Management of Individual Performance (pp.1-25). January.

[18] Vancouver, J. B., \& Schmitt, N. W. 1991. An exploratory examination of person organization fit: organizational goal congruence. Personnel Psychology, 44, 333-352. 